

science for a changing world

\title{
Evaluation of Geophysical Logs, Phase II, at Willow Grove Naval Air Station Joint Reserve Base, Montgomery County, Pennsylvania
}

Open-File Report 99-73 




prepared in cooperation with the

U.S. DEPARTMENT OF THE NAVY

\section{Evaluation of Geophysical Logs, Phase II, at Willow Grove Naval Air Station Joint Reserve Base, Montgomery County, Pennsylvania}

by Randall W. Conger

Open-File Report 99-73

U.S. Department of the Interior

U.S. Geological Survey 


\title{
U.S. DEPARTMENT OF THE INTERIOR
}

\section{BRUCE BABBITT, Secretary}

\author{
U.S. GEOLOGICAL SURVEY
}

Charles G. Groat, Director

For additional information write to:

District Chief

U.S. Geological Survey 840 Market Street

Lemoyne, Pennsylvania 17043-1586
Copies of this report may be purchased from:

U.S. Geological Survey

Branch of Information Services

Box 25286, Federal Center

Denver, Colorado 80225-0286 


\section{CONTENTS}



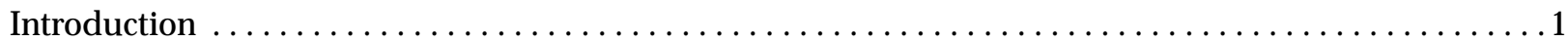

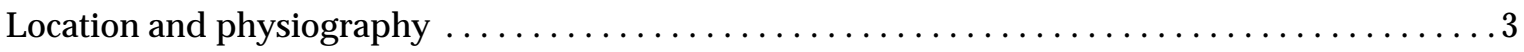

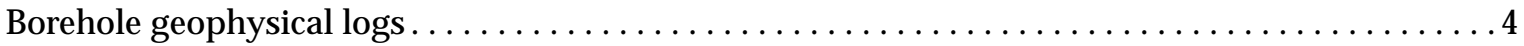

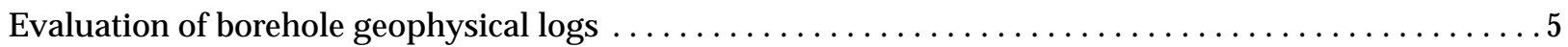

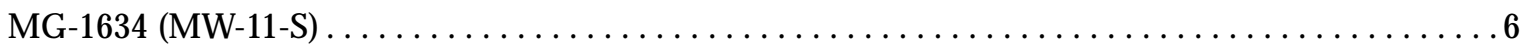

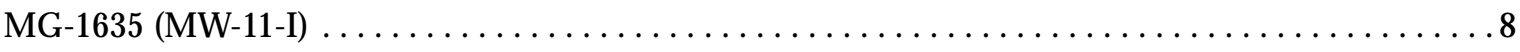

MG-1675 (Matrix Development Artesian Borehole) . ............................... 10

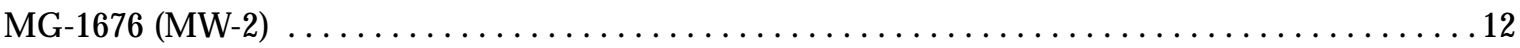



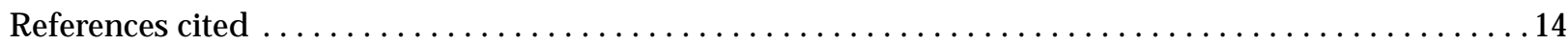

\section{ILLUSTRATIONS}

Figure 1. Map showing location of four contaminated sites at the Willow Grove Naval Air Station Joint Reserve Base, Montgomery County, Pa., and boreholes

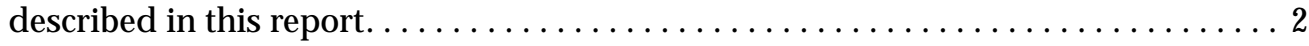

2-5. Graphs showing borehole-geophysical logs and direction of nonpumping flow within boreholes at the Willow Grove Naval Air Station Joint Reserve Base:

2. MG-1634 (MW-11-S) . . . . . . . . . . . . . . . . . . . . . . . . 7

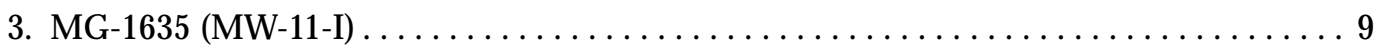

4. MG-1675 (Matrix Development Artesian Borehole) . . . . . . . . . . . . . . . . 11

5. MG-1676 (MW-2) ......................................... 13

\section{TABLES}

Table 1. Boreholes logged at Willow Grove Naval Air Station Joint Reserve Base, Montgomery County, Pennsylvania............................ 3

2. Well depth, casing length, and depth to water for boreholes logged by the

U.S. Geological Survey ................................ 5

3. Summary of heatpulse-flowmeter measurements for borehole MG-1634 (MW-11-S) . . 6

4. Summary of heatpulse-flowmeter measurements for borehole MG-1635 (MW-11-I) . . 8

5. Summary of heatpulse-flowmeter measurements for borehole MG-1676 (MW-2) . . . 12 


\section{CONVERSION FACTORS AND VERTICAL DATUM}

\begin{tabular}{lcl} 
Multiply & $\underline{\text { By }}$ & \multicolumn{1}{c}{ To obtain } \\
& $\underline{\text { Length }}$ & millimeter \\
inch $(\mathrm{in})$. & 25.40 & meter \\
foot $(\mathrm{ft})$ & 0.3048 & \\
& $\underline{\text { Volume }}$ & cubic meter per second \\
gallon per minute $(\mathrm{gal} / \mathrm{min})$ & 0.00006309 & \\
& $\underline{\text { Temperature }}$ & degree Fahrenheit
\end{tabular}

Sea level: In this report, "sea level" refers to the National Geodetic Vertical Datum of 1929—a geodetic datum derived from a general adjustment of the first-order level nets of the United States and Canada, formerly called Sea Level Datum of 1929. 


\title{
Evaluation of Geophysical Logs, Phase II, at Willow Grove Naval Air Station Joint Reserve Base, Montgomery County, Pennsylvania
}

\author{
by Randall W. Conger
}

\begin{abstract}
Between March and April 1998, the U.S. Navy contracted Tetra Tech NUS Inc., to drill two monitor wells in the Stockton Formation at the Willow Grove Naval Air Station Joint Reserve Base, Horsham Township, Montgomery County, Pa. The wells MG-1634 and MG-1635 were installed to monitor water levels and sample contaminants in the shallow, intermediate, and deep water-producing zones of the fractured bedrock. Chemical analyses of the samples will help determine the horizontal and vertical distribution of any contaminated ground water migrating from known contaminant sources. Wells were drilled near the Fire Training Area (Site 5). Depths of all boreholes range from 69 to 149 feet below land surface.

The U.S. Geological Survey conducted borehole geophysical logging and video surveys to identify water-producing zones in newly drilled monitor wells MG-1634 and MG-1635 and in wells MG-1675 and MG-1676. The logging was conducted from March 5, 1998, to April 16, 1998. This work is a continuation of the Phase I work.

Caliper logs and video surveys were used to locate fractures; inflections on fluid-temperature and fluid-resistivity logs were used to locate possible water-producing fractures. Heatpulse-flowmeter measurements were used to verify the locations of water-producing or water-receiving zones and to measure rates of flow between water-bearing fractures. Single-point-resistance and natural-gamma logs provided information on stratigraphy. After interpretation of geophysical logs, video surveys, and driller's notes, wells MG-1634 and MG-1635 were screened such that water-levels fluctuations could be monitored and discrete water samples collected from one or more water-producing zones in each borehole.
\end{abstract}

\section{INTRODUCTION}

The Willow Grove Naval Air Station Joint Reserve Base (NAS) is located in Montgomery County, Pa., on the U.S. Geological Survey (USGS) Ambler 7.5-minute topographic quadrangle map (fig. 1). In addition to its primary use as a reserve Naval Air Station, this 1,000-acre facility also supports U.S. Marine and U.S. Army activities. The U.S. Air Force has property holdings within the NAS boundary and shares common facilities with the NAS. Four major contaminated sites within the NAS (fig. 1) were identified as part of a Preliminary Assessment program (Halliburton NUS Environmental Corporation, 1996). A hydrogeological investigation is being conducted as part of the Navy's Installation Restoration Program to address ground-water contamination at these (and other) sites at NAS. The U.S. Navy requested that USGS provide technical assistance to their hydrological investigation. Specifically, the USGS was asked to conduct borehole geophysical logging to identify water-producing zones that could be monitored by properly completed wells. 


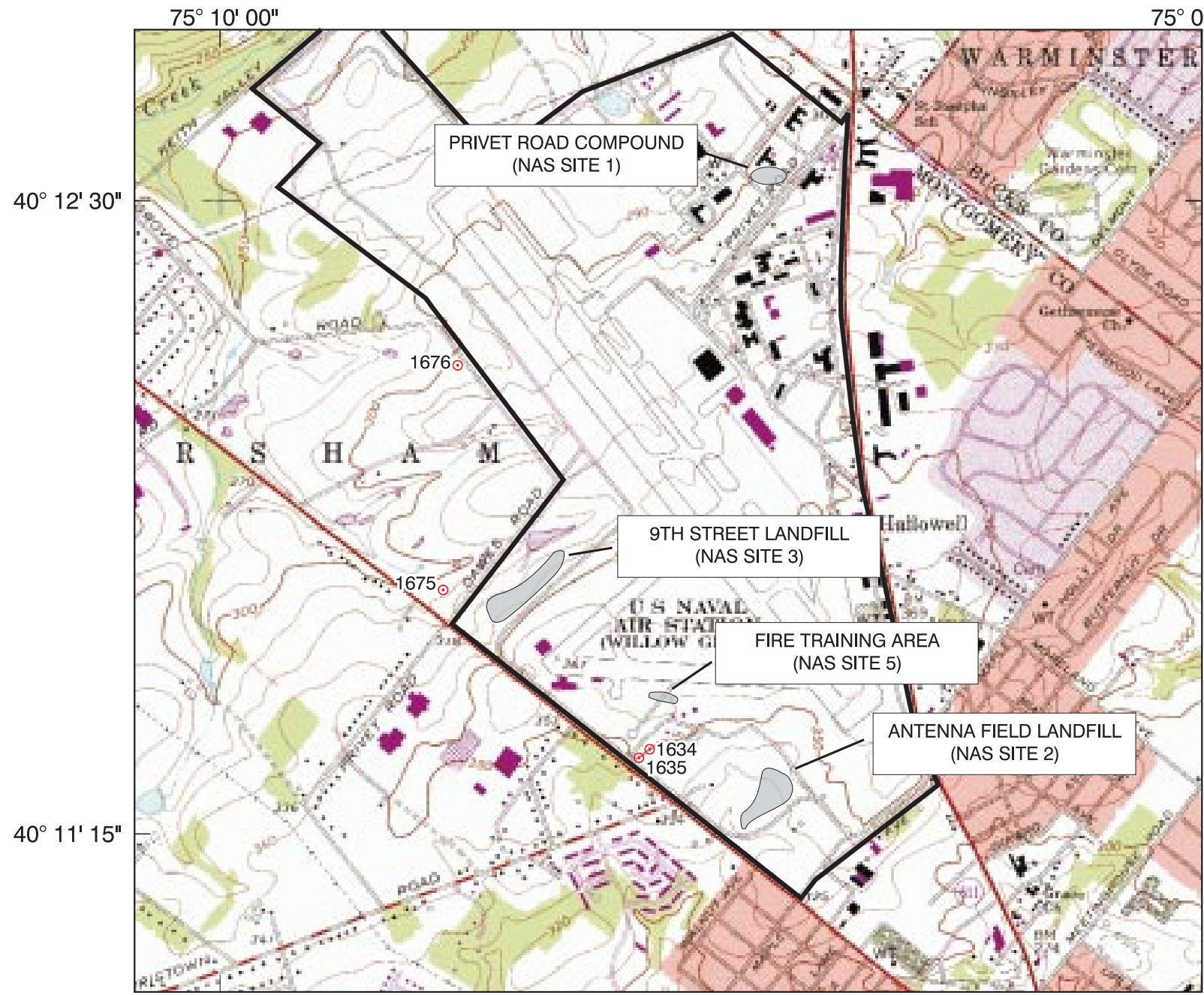

Base from U. S. Geological Survey Ambler 1:24,000, 1983
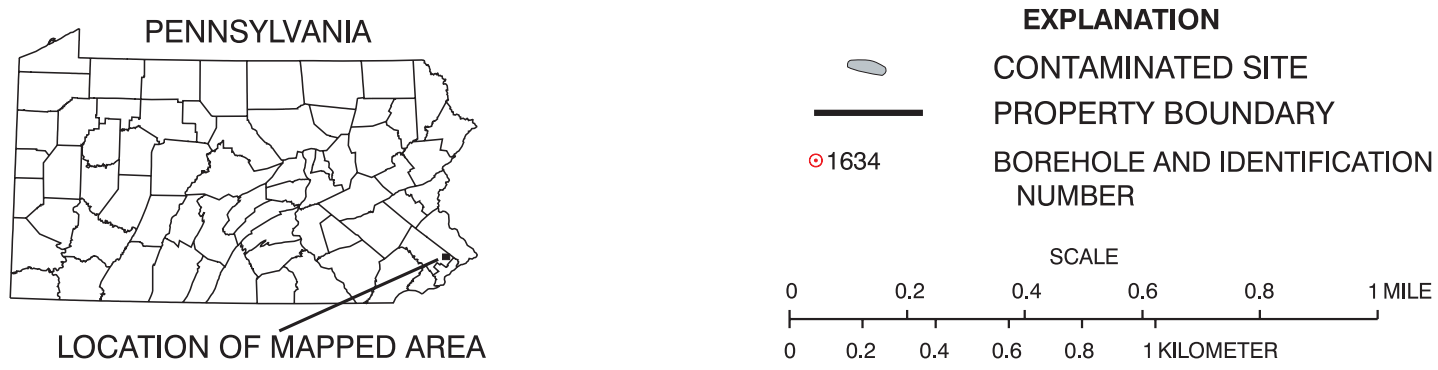

Figure 1. Location of four contaminated sites at the Willow Grove Naval Air Station Joint Reserve Base, Montgomery County, Pa., and boreholes described in this report. 
This report evaluates borehole geophysical logs and video surveys collected by the USGS in four boreholes at and adjacent to NAS from March 5, 1998, to April 16, 1998 (table 1 and fig. 1). One or more water-producing zones in each well are identified on the basis of the geophysical logs and video surveys. This work is a continuation of the Phase I work reported by Conger (1997). Caliper, natural-gamma, single-point-resistance, fluid-resistivity, and fluid-temperature logs, heatpulse-flowmeter measurements, and borehole video surveys were conducted in four boreholes. A cross-reference between USGS boreholeidentification numbers and Tetra Tech NUS Inc. (TTNUS), borehole-identification numbers and a list of logs collected in each borehole are shown in table 1.

Table 1. Boreholes logged at Willow Grove Naval Air Station Joint Reserve Base, Montgomery County, Pennsylvania

[B, borehole video; C, caliper log; G, natural-gamma log; R, single-point-resistance log; F, fluid-resistivity log; T, fluid-temperature log; V, heatpulse-flowmeter measurement]

\begin{tabular}{llrl}
\hline $\begin{array}{c}\text { U.S. Geological } \\
\begin{array}{c}\text { Survey borehole- } \\
\text { identification } \\
\text { number }\end{array}\end{array}$ & $\begin{array}{c}\text { Brown and Root } \\
\text { Environmental Inc. }\end{array}$ & $\begin{array}{c}\text { Depth } \\
\text { logged } \\
\text { (feet) }\end{array}$ & $\begin{array}{c}\text { Geophysical } \\
\text { logs collected }\end{array}$ \\
\hline MG-1634 & MW-11-S & 69 & B, C, G, R, F, T, V \\
MG-1635 & MW-11-I & 149 & B, C, G, R, F, T, V \\
MG-1675 & Matrix Development Artesian Borehole & 73 & B, C, G, R, F, T, V \\
MG-1676 & MW-2 & 149 & B, C, G, R, F, T, V \\
\hline
\end{tabular}

\section{Location and Physiography}

The NAS is within the Gettysburg-Newark Lowlands Section of the Piedmont Physiographic Province. The site and surrounding area are underlain by the Stockton Formation, which consists of sedimentary rocks of Triassic age. The Stockton Formation is subdivided into three lithologic units known as the lower arkose, middle arkose, and upper shale members (Rima and others, 1962). The middle arkose member crops out at the site. At the NAS, this unit consists of fine- to medium-grained arkosic sandstone interbedded with red siltstone and mudstone. Quartz and feldspar are the dominant minerals.

The Stockton Formation is about 6,000 ft thick at the Bucks-Montgomery County border; the middle arkose member has a maximum thickness of 4,200 ft (Rima and others, 1962). Bedding in the Stockton Formation at the NAS generally strikes NE-SW and dips an average of $12^{\circ} \mathrm{NW}$ (Rima and others, 1962). Vertical fractures are common. Primary ground-water storage and movement within the Stockton Formation is through secondary openings such as interconnected fractures, bedding planes, and joints (Sloto and others, 1995). Deeper wells may penetrate several major water-producing zones with different hydraulic properties that are under different hydraulic head. Thus, wells penetrating more than one water-producing zone are multiaquifer wells (Sloto and others, 1995). The hydraulic head in a multiaquifer well is a composite of the heads of the several water-producing zones it includes. In areas where hydraulic head differs between water-producing zones, water in a well either flows up or down the well bore in the direction of lower head (Sloto and others, 1995).

Ground water at the NAS originates from infiltration of precipitation and inflow of ground water from upgradient areas. Ground-water levels fluctuate with seasonal variations in recharge and also are influenced by pumping of nearby wells. Water in the upper part of the aquifer generally is under unconfined (water-table) conditions; ground water in the deeper part of the aquifer may be confined or partially confined. Local artesian conditions are common. Boreholes MG-1675 and MG-1676, located 3,126 and 5,228 ft, respectively, to the northwest from MG-1634 and MG-1635, were down dip, hydraulically down gradient, lower in elevation, and showed upward borehole flow. 


\section{Borehole Geophysical Logs}

Geophysical logs provide information on location of fractures and water-producing and waterreceiving zones (caliper logs and video surveys) and intervals of vertical borehole flow (fluid-resistivity and fluid-temperature logs), quantification of borehole flow (heatpulse-flowmeter measurements), lithologic correlation (gamma and single-point-resistance logs), and well construction (caliper and singlepoint-resistance logs).

Caliper logs record the average borehole diameter, which may be related to fractures, lithology, or drilling methods. Caliper logs are used to identify fractures and possible water-producing openings and to correct other geophysical logs for changes in borehole diameter. Correlation of caliper logs with fluidresistivity and fluid-temperature logs is used to identify fractures, water-producing zones, and waterreceiving zones and to measure water velocity.

The term fracture used in association with the caliper-log interpretations might identify a change in borehole diameter that may not necessarily indicate a bedding-plane separation, lithologic contact, or fluid-producing or fluid-receiving zones but may simply indicate an enlargement of the borehole.

The natural-gamma or gamma log measures the natural-gamma radiation (photons) emitted from rocks penetrated by the borehole. The most common emitters of gamma radiation are uranium-238 and thorium-232 and their daughter elements and potassium-40. These radioactive elements are concentrated in clays by adsorption, precipitation, and ion exchange. Fine-grained sediments, such as shale or siltstone, usually emit more gamma radiation than sandstone, limestone, or dolomite. Geophysical logging with a gamma probe can be conducted in the fluid-filled, dry, cased, or uncased parts of a borehole. However, casing does reduce the gamma response. The gamma log is used to correlate geologic units between wells (Keys, 1990).

The single-point-resistance log records the electrical resistance of a formation between the probe in a water-filled borehole below casing and an electrical ground at land surface. Generally, electrical resistance increases with formation grain size and decreases with increasing borehole diameter, water-bearing fractures, and increasing dissolved-solids concentration of borehole fluid. The single-point-resistance log is used to correlate geology and lithology between wells and may help identify formation water-bearing zones. (Keys, 1990).

Fluid resistivity is the inverse of fluid conductivity. The fluid-resistivity log measures the electrical resistivity of the water column in the well. The fluid-resistivity probe measures the resistivity of borehole water between electrodes in the probe. Fluid-resistivity logs reflect changes in the dissolved-solids concentration of water in the borehole. Fluid-resistivity logs are used to identify water-producing and water-receiving zones and to determine intervals of vertical borehole flow. Water-producing and waterreceiving zones usually are identified by distinct changes in resistivity. Intervals of vertical borehole flow are usually identified by a low-resistivity gradient between a water-producing and a water-receiving zone. Also, zones of salt water intrusion and some types of contaminant plumes can be identified.

Fluid-temperature logs provide a continuous record of the temperature of fluid in a borehole. Temperature logs are used to identify water-producing and water-receiving zones and to determine zones of vertical borehole flow. Intervals of vertical borehole flow are characterized by little or no temperature gradient. (Williams and Conger, 1990).

The direction and rate of borehole-fluid movement was determined by the use of a heatpulse flowmeter. The heatpulse flowmeter operates by heating a small sheet of water between two sensitive thermistors (heat sensors). A measurement of direction and rate is computed when a peak temperature is recorded by one of the thermistors. The range of flow measurement is about $0.01-1.5 \mathrm{gal} / \mathrm{min}$ in a 2 - to 10-in. diameter borehole (Conger, 1996). 
Some heatpulse-flowmeter measurements may be influenced by (1) poor seal integrity between the borehole and heatpulse flowmeter, and (2) contributions of water from storage within the borehole. If the seal between the borehole and flowmeter is not complete, some water can bypass the flowmeter, resulting in measurements of flow that are less than the actual rate. Although the heatpulse flowmeter is a calibrated probe, the data are used primarily as a relative indicator to identify water-producing zones.

Video surveys were conducted by lowering a waterproof camera down the borehole and recording the image on video tape. The depth indicated on the video survey may not correspond exactly to the geophysical logs because of some minor slippage (plus or minus $1 \mathrm{ft}$ ) of the video cable.

\section{EVALUATION OF BOREHOLE GEOPHYSICAL LOGS}

The locations of boreholes logged are shown on figure 1 . The reference measuring point for all geophysical logs and video surveys is in feet below land surface. Depth of wells, casing lengths, and water levels at the time of logging are given in table 2 .

Table 2. Well depth, casing length, and depth to water for boreholes logged by the U.S. Geological Survey at Willow Grove Naval Air Station Joint Reserve Base, Montgomery County, Pennsylvania

\begin{tabular}{llcccc}
\hline $\begin{array}{c}\text { U.S. Geological } \\
\begin{array}{c}\text { Survey borehole- } \\
\text { identification } \\
\text { number }\end{array}\end{array}$ & $\begin{array}{c}\text { Brown and Root } \\
\text { Environmental Inc. }\end{array}$ & $\begin{array}{c}\text { Depth of } \\
\text { well below } \\
\text { land surface } \\
\text { (feet) }\end{array}$ & $\begin{array}{c}\text { Length of } \\
\text { casing below } \\
\text { land surface } \\
\text { (feet) }\end{array}$ & $\begin{array}{c}\text { Depth to } \\
\text { water below } \\
\text { land surface } \\
\text { (feet) }\end{array}$ & $\begin{array}{c}\text { Date } \\
\text { water level } \\
\text { measured }\end{array}$ \\
\hline MG-1634 & MW-11-S & 67 & 18.5 & 6.4 & $4 / 16 / 98$ \\
MG-1635 & MW-11-I & 149 & 18 & 5.75 & $4 / 16 / 98$ \\
MG-1675 & Matrix Development Artesian Borehole & 72 & 29 & $\begin{array}{c}\text { Above land } \\
\text { surface } \\
\text { (flowing) }\end{array}$ \\
MG-1676 & MW-2 & & $149 / 5 / 98$ & 9.35 & $3 / 10 / 98$ \\
\hline
\end{tabular}




\section{MG-1634 (MW-11-S)}

The caliper log shows the total depth of the borehole is $67 \mathrm{ft}$ and it is cased with 6-in.-diameter casing to $18.5 \mathrm{ft}$ below land surface (bls) (fig. 2). The caliper log shows major fractures at 18.5-23, 30.5, 38, 48 , and $50 \mathrm{ft}$ bls plus numerous minor fractures. The static water level was $6.4 \mathrm{ft}$ bls at the time of logging. The fluid-resistivity log shows changes in slope at 20 and $30 \mathrm{ft}$ bls that correlate to fractures shown on the caliper log. The fluid-temperature log shows changes in slope at 19-23, 38, and $54 \mathrm{ft}$ bls that correlate to fractures zones shown on the caliper log. Under nonpumping conditions, the heatpulse flowmeter measured downward flow at 29, 33, 41, and $53 \mathrm{ft} \mathrm{bls}$ and no flow at $62 \mathrm{ft}$ bls (table 3). The video survey shows the borehole water starts to become cloudy at $54 \mathrm{ft}$ bls and very cloudy at $60 \mathrm{ft}$ bls, which indicates little or no borehole flow exists below these depths. The geophysical logs and the heatpulse-flowmeter measurements indicate water enters the borehole through fractures at $18.5-23 \mathrm{ft}$ bls and moves downward. A minor quantity of the water exits the borehole through fractures at $42-51 \mathrm{ft} \mathrm{bls}$; most water probably exits the borehole at $56 \mathrm{ft}$ bls, on the basis of the inflection noted on the fluid-temperature log. The driller's $\log$ shows the largest water-producing zone in the borehole was noted at $18.5-23 \mathrm{ft}$ bls; additional water was contributed from fractures at $43-47 \mathrm{ft}$ bls. Yield increased from $35-40 \mathrm{gal} / \mathrm{min}$ at $30 \mathrm{ft}$ bls to $70 \mathrm{gal} / \mathrm{min}$ at $43-47 \mathrm{ft}$ bls and then to $70-80 \mathrm{gal} / \mathrm{min}$ at $53 \mathrm{ft}$ bls. The total yield at the bottom of the borehole was $80 \mathrm{gal} / \mathrm{min}$. Screens were placed by TTNUS at 16-26 and 35-50 ft bls to include the water-producing fractures at $18.5-23$ and $45 \mathrm{ft}$ bls.

Table 3. Summary of heatpulse-flowmeter measurements for borehole MG-1634 (MW-11-S) at Willow Grove Naval Air Station Joint Reserve Base, Montgomery County, Pennsylvania

[ft bls, feet below land surface; gal/min, gallons per minute]

\begin{tabular}{ccc}
\hline $\begin{array}{c}\text { Depth } \\
\text { (ft bls) }\end{array}$ & $\begin{array}{c}\text { Flow rate under } \\
\text { nonpumping conditions } \\
\text { (gal/min) }\end{array}$ & $\begin{array}{c}\text { Flow direction under } \\
\text { nonpumping conditions }\end{array}$ \\
\hline 29 & 1.4 & Down \\
33 & 1.3 & Down \\
41 & 1.3 & Down \\
53 & .8 & Down \\
62 & No flow & Not determined \\
\hline
\end{tabular}



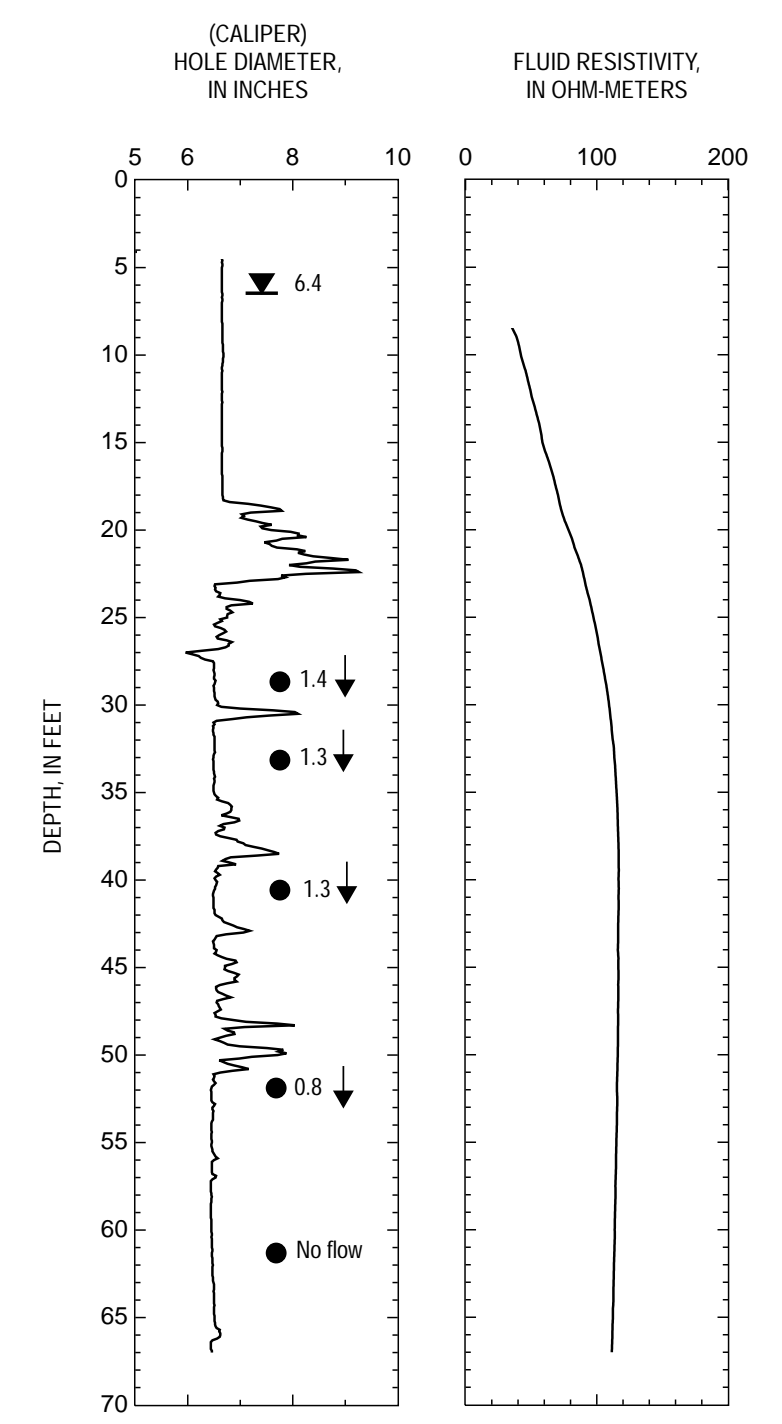

NATURAL GAMMA,
COUNTS PER SECON

SINGLE-POINT

FLUID TEMPERATURE,

RESISTANCE, IN OHMS

IN DEGREES CELSIUS


\section{EXPLANATION}

STATIC WATER LEVEL-

ב. measured in borehole at the

BOREHOLE-FLOW
MEASUREMENT UNDER

NONPUMPING CONDITIONS-

Circle at depth of flow

measurement. Number is

measured flow in gallons
per minute

DIRECTION OF BOREHOLE

CONDITIONS

Figure 2. Borehole-geophysical logs and direction of nonpumping flow within borehole MG-1634 (MW-11-S), Willow Grove Naval Air Station Joint Reserve Base. 


\section{MG-1635 (MW-11-I)}

The caliper log shows the total depth of the borehole is $149 \mathrm{ft}$ and it is cased with 6-in.-diameter casing to about $18 \mathrm{ft}$ bls (fig. 3). The caliper log shows major fractures at 19, 24-26, 41, 49, 65-67, and $102 \mathrm{ft} \mathrm{bls}$ and numerous minor fractures throughout the open-hole interval. The static water level was $5.75 \mathrm{ft}$ bls at the time of logging. The fluid-resistivity log shows a change in slope at $19 \mathrm{ft}$ bls that correlates to fractures on the caliper log. Also, the fluid-temperature log shows a change in slope at $24-28 \mathrm{ft}$ bls that correlates to fractures on the caliper log. Under nonpumping conditions, the heatpulse-flowmeter measured downward borehole flow at 34, 58, 80, 106, 124, and $140 \mathrm{ft}$ bls (table 4). The geophysical logs and the heatpulse-flowmeter measurements indicate water enters the borehole through the fractures at 19$28 \mathrm{ft}$ bls, moves downward, and exits the borehole at 130 and $146 \mathrm{ft}$ bls. The driller's log shows that during drilling the greatest water-producing zones are above $80 \mathrm{ft}$ bls. Yield increased from 10-15 gal/min at $25 \mathrm{ft}$ bls to $70-80 \mathrm{gal} / \mathrm{min}$ at $50 \mathrm{ft}$ bls and then increased with depth to $80-110 \mathrm{gal} / \mathrm{min}$ at the bottom. The total yield during drilling was $110 \mathrm{gal} / \mathrm{min}$. A screen was placed by TTNUS at 138-148 $\mathrm{ft}$ bls to include the fracture at $146 \mathrm{ft}$ bls.

Table 4. Summary of heatpulse-flowmeter measurements for borehole MG-1635 (MW-11-I) at Willow Grove Naval Air Station Joint Reserve Base, Montgomery County, Pennsylvania

[ft bls, feet below land surface; gal/min, gallons per minute]

\begin{tabular}{rcl}
\hline $\begin{array}{c}\text { Depth } \\
\text { (ft bls) }\end{array}$ & $\begin{array}{c}\text { Flow rate under } \\
\text { nonpumping conditions } \\
\text { (gal/min) }\end{array}$ & $\begin{array}{c}\text { Flow direction under } \\
\text { nonpumping conditions }\end{array}$ \\
\hline 34 & 1.4 & Down \\
58 & 1.4 & Down \\
80 & 1.3 & Down \\
106 & 1.4 & Down \\
124 & 1.4 & Down \\
140 & 1.2 & Down \\
\hline
\end{tabular}





FLUID TEMPERATURE,

IN DEGREES CELSIUS

Figure 3. Borehole-geophysical logs and direction of nonpumping flow within borehole MG-1635 (MW-11-I), Willow Grove Naval Air Station Joint Reserve Base. 


\section{MG-1675 (Matrix Development Artesian Borehole)}

The caliper log shows the total depth of the borehole is $71 \mathrm{ft}$ and it is cased with 6-in.-diameter casing to $29 \mathrm{ft}$ bls (fig. 4). The caliper log shows the casing interior is very rough and irregular. This is apparently because of rust and bacterial growth. The caliper log shows a major fracture at $64-67 \mathrm{ft}$ bls plus numerous minor fractures throughout the open-hole interval. The fluid-resistivity and the fluid-

temperature logs show a change in slope at $64 \mathrm{ft}$ bls that correlates to the major fracture at $64-67 \mathrm{ft}$ bls shown on the caliper log. Under nonpumping conditions, the borehole was under artesian conditions and was flowing at approximately $10 \mathrm{gal} / \mathrm{min}$. The video survey shows the borehole water becomes cloudy abruptly at $68 \mathrm{ft}$ bls indicating little or no borehole flow exists below that depth. The geophysical logs and the video survey indicate water enters the borehole through fractures at $64-67 \mathrm{ft}$ bls, moves upward, and discharges through the top of the casing above land surface. 

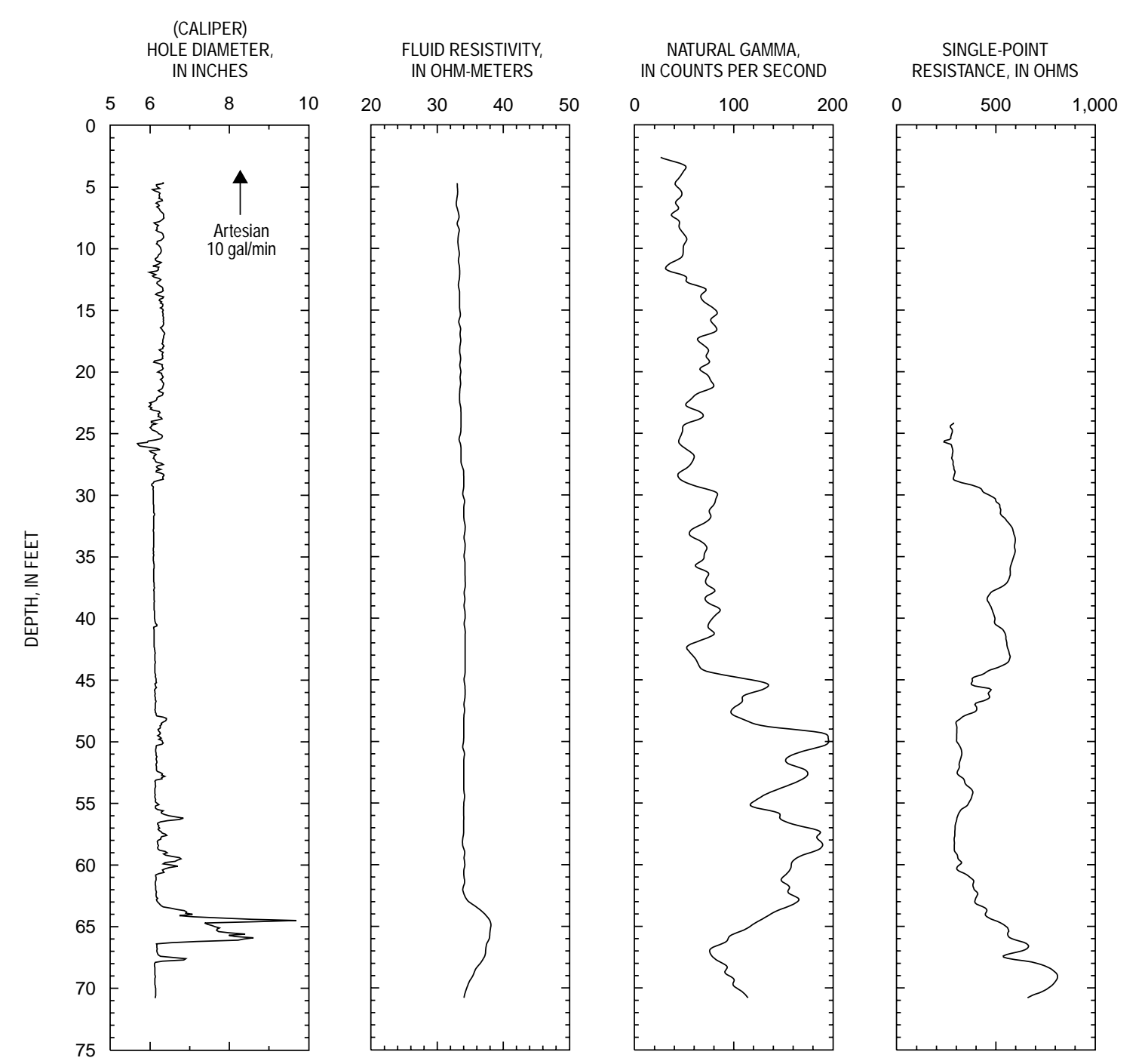

FLUID TEMPERATURE,

IN DEGREES CELSIUS
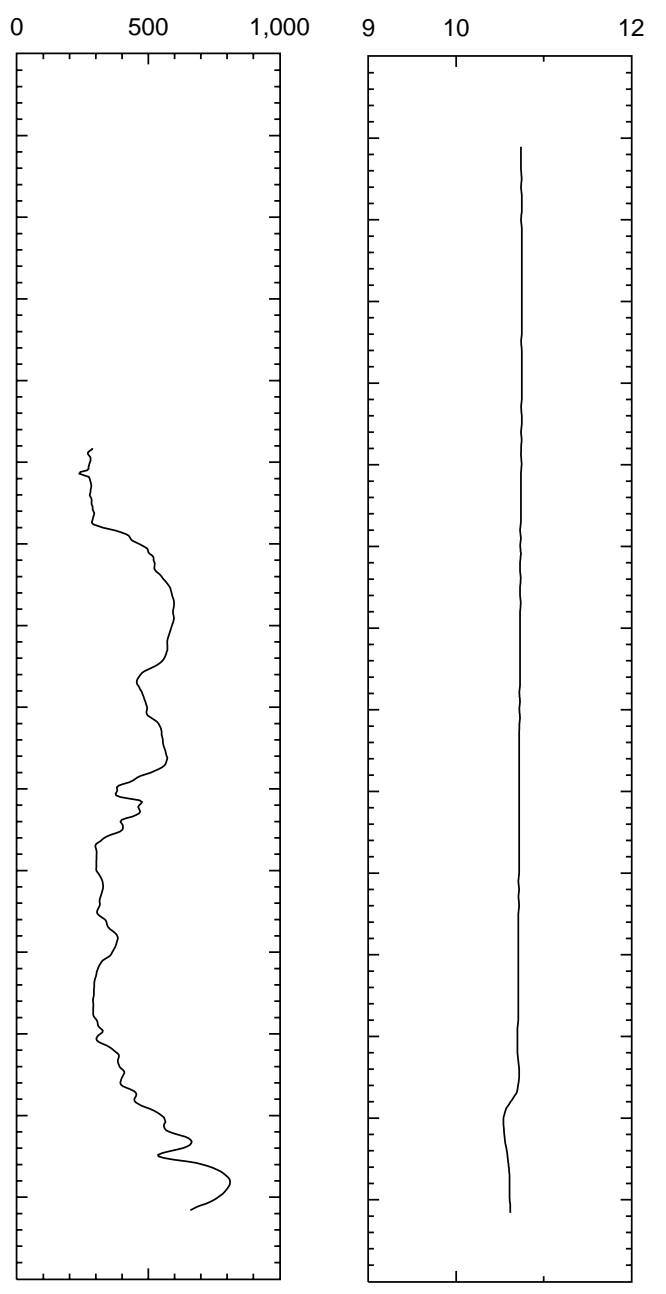

Figure 4. Borehole-geophysical logs and direction of nonpumping flow within borehole MG-1675 (Matrix Development Artesian Borehole), Willow Grove Naval Air Station Joint Reserve Base. 


\section{MG-1676 (MW-2)}

The caliper log shows the total depth of the borehole is $149 \mathrm{ft}$ and it is cased with 6-in.-diameter casing to $24 \mathrm{ft}$ bls (fig. 5). The caliper log shows major fractures at $24.5-27$ and $89 \mathrm{ft}$ bls plus numerous minor fractures throughout the open-hole interval. The static water level was $9.35 \mathrm{ft}$ bls at the time of logging. The fluid-resistivity and fluid-temperature logs show changes in slope at $32 \mathrm{ft}$ bls that correlate to minor fractures shown on the caliper log. The natural-gamma log shows a shale unit with elevated gamma readings at 121-122 ft bls that might be used for stratigraphic correlation of geologic units with other wells. Under nonpumping conditions, the heatpulse flowmeter measured upward borehole flow at $42,66,86$, 100 , and $118 \mathrm{ft}$ bls and no flow at 30 and $134 \mathrm{ft}$ bls (table 5). The video survey shows the borehole water generally has low visibility and becomes more cloudy at 24-30 ft bls and below $125 \mathrm{ft}$ bls. This indicates that little or no borehole flow exists within these intervals. The geophysical logs and the heatpulseflowmeter measurements indicate water enters the borehole through fractures at 125 and $89-97 \mathrm{ft} \mathrm{bls,}$ moves upward, and exits the borehole through fractures at 32-38 ft bls. The heatpulse-flowmeter measurements were inconsistent at some depth locations, suggesting that the hydraulic head in the borehole may be affected by a nearby pumping well.

Table 5. Summary of heatpulse-flowmeter measurements for borehole MG-1676 (MW-2) at Willow Grove Naval Air Station Joint Reserve Base, Montgomery County, Pennsylvania

[ft bls, feet below land surface; gal/min, gallons per minute]

\begin{tabular}{rcc}
\hline $\begin{array}{c}\text { Depth } \\
\text { ft bls) }\end{array}$ & $\begin{array}{c}\text { Flow rate under } \\
\text { nonpumping conditions } \\
\text { (gal/min) }\end{array}$ & $\begin{array}{c}\text { Flow direction under } \\
\text { nonpumping conditions }\end{array}$ \\
\hline 30 & No flow & Not determined \\
42 & $0.5-1.0$ & $\mathrm{Up}$ \\
66 & .5 & $\mathrm{Up}$ \\
86 & $.5-.8$ & $\mathrm{Up}$ \\
100 & .3 & $\mathrm{Up}$ \\
118 & .2 & $\mathrm{Up}$ \\
134 & No flow & Not determined \\
\hline
\end{tabular}



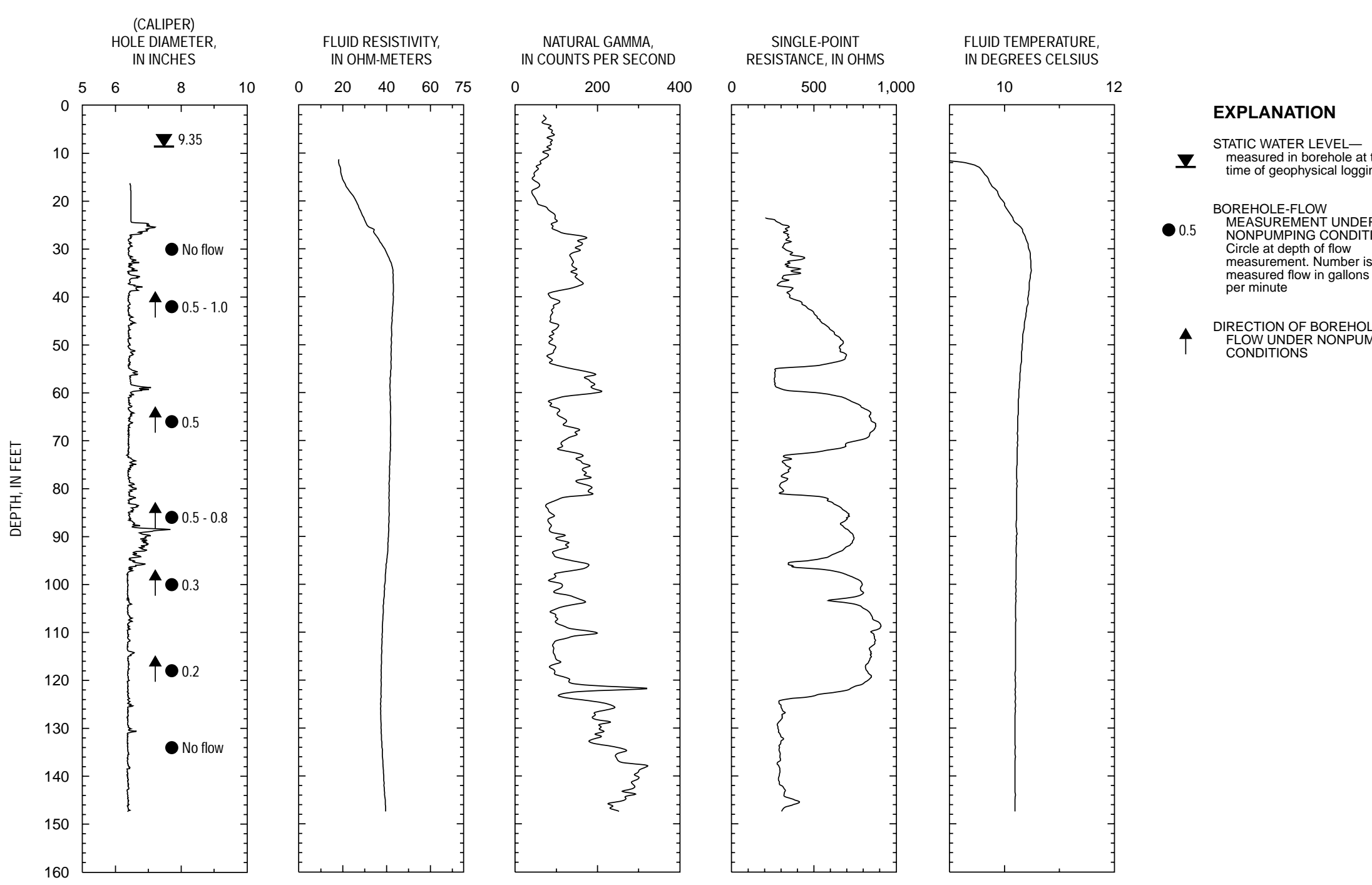

EXPLANATION

工 $\begin{gathered}\text { STATIC WATER LEVEL- } \\ \text { measured in borehole at the } \\ \text { time of geophysical logging }\end{gathered}$ BOREHOLE-FLOW
MEASUREMENT UNDER
NONPUMPING CONDITIONSCircle at depth of flow measurement. Number is measured flow in gallons
per minute

DIRECTION OF BOREHOLE
FLOW UNDER NONPUMPING
CONDITIONS

Figure 5. Borehole-geophysical logs and direction of nonpumping flow within borehole MG-1676 (MW-2), Willow Grove Naval Air Station Joint Reserve Base. 


\section{CONCLUSIONS}

The Willow Grove Naval Air Station Joint Reserve Base and surrounding area are underlain by the Stockton Formation, which consists of sedimentary rocks of Triassic Age. Water-producing zones, waterreceiving zones, and intervals of vertical borehole flow were identified by the use of geophysical logs, heatpulse-flowmeter measurements, video surveys, and driller's notes. This enabled Tetra Tech NUS to place screens at selected water-producing intervals so that these zones could be sampled in newly drilled boreholes MG-1634 and MG-1635 and identify the water-producing and water-receiving zones in boreholes MG-1675 and MG-1676.

Boreholes MG-1634 and MG-1635 near Site 5 showed downward nonpumping flow. In these boreholes, water is generally produced through fractures between $18-28 \mathrm{ft}$ bls, moves downward, and exits the borehole through fractures between $56-146 \mathrm{ft}$ bls, depending on the borehole depth. Boreholes MG-1675 and MG-1676, located 3,126 and 5,228 ft, respectively, to the northwest from MG-1634 and MG-1635, were down dip, down hydraulic gradient, and showed upward borehole flow. These wells are located approximately $50 \mathrm{ft}$ lower topographically than wells near NAS Site 5 and are in an area where ground-water discharges to a local stream.

The video surveys show that the wells become even more cloudy in zones of no borehole flow. Geophysical and drilling logs, video surveys, and heatpulse-flowmeter measurements indicate all boreholes penetrate 3 water-producing zones depending on well depth; a shallow unconfined and two semi-confined or confined zones. The shallow and intermediate boreholes near NAS Site 5 are reported to produce 80-110 gal/min. Generally, borehole water yield increases with depth to about $150 \mathrm{ft}$ bls locally (Conger, 1997). The vertical direction of borehole flow in an open borehole is dependent on depth and elevation of the water-producing intervals.

\section{REFERENCES CITED}

Conger, R.W., 1996, Borehole geophysical logging for water-resources investigations in Pennsylvania: U.S. Geological Survey Fact Sheet 218-95, 4 p.

1997, Evaluation of geophysical logs, Phase I, at Willow Grove Naval Air Station, Montgomery County, Pennsylvania: U.S. Geological Survey Open-File Report 97-631, 49 p.

Halliburton NUS Environmental Corporation, 1993, Remedial investigation report for sites 1, 2, 3, and 5, Naval Air Station, Willow Grove, Pennsylvania: Wayne, Pa., Halliburton NUS Corporation, 2 v.

Keys, W.S., 1990, Borehole geophysics applied to ground-water investigations: U.S. Geological Survey Techniques of Water-Resources Investigations, book 2, chap. E2, 150 p.

Rima, D.R., Meisler, Harold, and Longwill, Stanley, 1962, Geology and hydrology of the Stockton Formation in southeastern Pennsylvania: Pennsylvania Geology Survey, 4th ser., Water Resources Report 14, 111 p., 4 pls.

Sloto, R.A., Macchiaroli, Paola, and Conger, R.W., 1995, Geohydrology and vertical distribution of volatile organic compounds in groundwater, Fischer and Porter Company Superfund Site, Warminster, Bucks County, Pennsylvania: U.S. Geological Survey Water-Resources Investigations Report 95-4220, 16 p.

Williams, J.H., and Conger, R.W., 1990, Preliminary delineation of contaminated water-producing fractures intersected by open-hole bedrock wells: Groundwater Monitoring Review, Fall 1990, p. 118-126. 